1 Highway, east of Regina, no doubt casualties of the same bad weather. On May 13 single specimens of three additional species-House Sparrow, Tree Sparrow and Snow Buntingwere found by us on the CKCK station roof, out these were all one to fcur weeks old.

One Swainson's Thrush, among those found by the Tempel party, exhibited random partial albinism. White feathers occurred irregularly in the plumage as follows: on the top of the head, on the nape and back of the lower neck, on the sides of the head at the angle of the jaws, a lesser covert on the right: wing, in the scapulars and on the back and rump. Areas which were especially affected were the nape and sides of the head (29 feathers), and the rump (10 feathers). $\dot{A}$ total of 48 white feathers was counted; in all cases, the whole feather was pure white. The bird was apparently otherwise normal.

\section{TABLE I-Birds recovered}

1. Swainson's Thrush

2. Gray-cheeked Thrush

3. Blackpoll Warbler

4. Savannah Sparrow

5. Clay-colored Sparrow

6. White-crowned Sparrow Totals

\begin{tabular}{cccc} 
at & TV tower, May & 12-May \\
May 12 & May 13 & Combined \\
& 14 & 9 & 23 \\
& 11 & 14 & 25 \\
& 3 & 2 & 5 \\
& 2 & 2 & 4 \\
& -1 & 1 & 1 \\
& 1 & - & 1 \\
\hline
\end{tabular}

13,1962

Male Female 158

$14 \quad 11$

41

$-\quad \frac{1}{1}$

\begin{tabular}{l}
1 \\
$-\quad 1$ \\
\hline
\end{tabular}

\title{
Fall Migration TV Tower Kills, 1962
}

by Fred Lahrman, Sask. Museum of Natural History

The TV towers at Regina, Moose Jaw and Caron were checked on selected weekends during September and October by myself and other members of the staff of the Saskatchewan Museum of Natural History. In summarizing the kills noted on these occasions, we were once more struck by the fact that the species represented and the numbers involved in the kill did not necessarily coincide with those most commonly reported for the same dates by persons observing the fall migrants that normally come down in the area.

On September 7, 1962, I visited the CICK TV tower at Regina with A. Swanston, R. Carson and F. Bard, and recovered 52 birds of 14 species, as follows: Red-eyed Vireo (10), Philadelphia Vireo (1), Warbling Vireo (1), Tennessee Warbler (4), Yellow Warbler (3), Bay-breasted Warbler (5), Blackpoll Warbler (2), Palm Warbler (1), Ovenbird (13), Northern Waterthrush (4), Connecticut Warbler (3), Yellowthroat (1), Wilson's Warbler (3), House Sparrow (1). The number of Baybreasted Warblers (5) among the warblers found on this date fits in with the three birds of this species, formerly regarded as very rare in Regina, which were recovered by $R$. W. Nero at the Regina TV tower on
September 3, 1961 (see Blue Jay, 19:161).

The following day, September 8, Mr. Bard and I checked the TV tower at Moose Jaw, finding 1 Sora and 1 Savannah Sparrow.

On the weekend of October 6-7, two visits were paid to the CKCK TV tower at Regina when the species recovered of course differed noticeably from those reported a month previously. The most interesting find was a Yellow Rail which I picked up on October 7 and reported to Margaret Belcher as a new record for the check-list of the birds of Regina. In addition, we recovered Common Snipe ( 2 on Oct. 7), Swainson's Thrush (2 on Oct. 6; 1 on Oct. 7), Grey-cheeked Thrush (1 on Oçt. 7), Orangecrowned Warbler (5 on Oct. $6 ; 3$ on Oct. 7), Myrtle Warbler (3 on Oct. $6 ; 1$ on Oct. 7), Yellowthroat ( 1 on Oct. 6), Savannah Sparrow (3 on Oct. 6), Vesper Sparrow (1 on Oct. 7).

At Caron, five visits were made to the TV tower in September, with the following recoveries: Sept. 9-Coot (1), Swainson's Thrush (1); Sept. 12 -Sora (2), Chestnut-sided Warbler (1) (my first fall migration record); Sept. 14-Red-eyed Vireo (1); Sept. 15-Ovenbird (1); Sept. 30-Sparrow Hawk (1) (dead for several days). 